\title{
TRACE METALS BINDING TO HUMIC AND FULVIC ACIDS FROM SURFACIAL SEDIMENTS OF LAKE MANZALAH, EGYPT.
}

\author{
Mohamed A. Okbah ${ }^{1}$ and Mohamed A. Hamed ${ }^{2}$ \\ 1- National Institute of Oceanography and Fisheries, kayet bay, \\ Alexandria, Egypt \\ 2- National Institute of Oceanography and Fisheries, Suez, Egypt
}

Key words: Trace metals, humic acid, fulvic acid, Lake Manzalah, sediments.

\section{ABSTRACT}

1 welve sediment samples were collected from Lake Manzalah during summer, 2004 to examine the influence of dissolved humic and fulvic acids on the distribution of trace metals in surficial sediments of the Lake.

Trace metal concentrations in the humic acid extracted from the Lakc sediments showed considerably high contents of iron $(1046-3069 \mu \mathrm{g} / \mathrm{g}$ ); copper $(234-1498 \mu \mathrm{g} / \mathrm{g})$ and zinc $(110-394 \mu \mathrm{g} / \mathrm{g})$. The other trace metals $(\mathrm{Co}, \mathrm{Cd}, \mathrm{Cr}, \mathrm{Ni}$ and $\mathrm{Mn}$ ) revealed low concentrations, ranging from 11.3 to $156 \mu \mathrm{g} / \mathrm{g}$. The metal concentrations in fulvic acid were in the following order: Fe (465-2767 $\mu \mathrm{g} / \mathrm{g}) ; \mathrm{Cu}(49.6-250.6 \mu \mathrm{g} / \mathrm{g}) ; \mathrm{Zn}(49.3-186.6 \mu \mathrm{g} / \mathrm{g})$; $\mathrm{Cd}(39.6-80.8 \mu \mathrm{g} / \mathrm{g}) ; \mathrm{Ni}(20.4-153.4 \mu \mathrm{g} / \mathrm{g}) ; \mathrm{Co}(12.5-78.0 \mu \mathrm{g} / \mathrm{g}) ; \mathrm{Mn}$ $(11.8-55.9 \mu \mathrm{g} / \mathrm{g})$ and $\mathrm{Cr}(9.1-39.6 \mu \mathrm{g} / \mathrm{g})$. The values of $\mathrm{Cu}$ and $\mathrm{Cd}$ percentage associated with the humic acid were high comparing with that reported in the other metals. This relative percentage was decreased for the same metals in association with fulvic acid. In general, the results indicated that the amounts of trace metals in humic acids decreased as follows: $\mathrm{Fe}>\mathrm{Cu}>\mathrm{Zn}>\mathrm{Ni}>\mathrm{Co}>\mathrm{Cd}>\mathrm{Mn}>\mathrm{Cr}$. While in fulvic acid the order was: $\mathrm{Fe}>\mathrm{Cu}>\mathrm{Zn}>\mathrm{Cd}>\mathrm{Ni}>\mathrm{Co}>\mathrm{Mn}>\mathrm{Cr}$.

\section{INTRODUCTION}

Lake Manzalah is covered with macophytes and floating plants which are characterized by their potentiality in assimilation of nutrients and heavy metals from the water and sediments. El-Saraaf (1995) showed that there is potential contamination of aquatic macrophytes by trace metals $(\mathrm{Pb}, \mathrm{Cd}, \mathrm{Zn}, \mathrm{Fe}$ and $\mathrm{Cu})$. These plants play an important role in the constituents of humic substances. The lake receives heavy loads of 
organic and inorganic pollutants via drains. Organic matters in the lake are one of the important sediment components. The previous studies showed high content of organic carbon in the lake sediments, ranged from 0.9 to $9.5 \%$.The lake receives about $7500 \times 10^{6} \mathrm{~m}^{3}$ of untreated industrial, domestic and drainage water annually, as well as agrochemicals and about $3 \times 10^{6} \mathrm{~m}^{3}$ of this wastewater is heavily loaded with organic matter and pollutants, which outflow daily into the Mediterranean Sea (AbdelBaky et al., 1991; Ibrahim et al., 1997 ; El-Sherif \& Gharib, 2001). The results recorded by El-shebly (2002) showed that heavy metals concentrations in fish muscles were above the recommended standard of the USEPA and the Egyptian laws; the levels of the metals content represent a potential human health hazard .

Many absorbent substrates in the natural environment are known to have a strong reaction with respect to the transfer of many pollutants, including the trace metals. Among these substrates are clays, organic matter and its subfractions (humic substances). Humic substances are natural dissolved organic polyelectrolyte formed by breakdown of animals and vegetables matter in soils, sediments and water environments. Generally, they form the major fraction of dissolved organic matter that represents $90 \%$ of dissolved organic carbon (Zhou et al., 1994 ; Liu \& Gonzalez, 1999). The classical view states of humic substances are macromolecular, negatively charged that contain mainly carboxylic and phenolic functional groups as well as hydroxyl, amine and quinone groups, which provide a number of different potential binding sites for metal ions (Swift, 1989). Humic substances are divided into three crude fractions based on their solubility in aqueous acids and basis; humin, humic acid and fulvic acid. Each fraction is a mixture of organic substances having a wide range of molecular weights and negative charges, with varying structural and functional properties (Hayes \& Swift, 1990 ; Stevenston, 1994). Each fraction has a strong ability to interact with metal ions, oxides, hydroxides, minerals and other organic substances to form water stable associations (Schnitzer, 1989; LeBoeufand \& Weber, 2000). The interactions between trace metals and humic substances affect the potential for transport of the metals by either increasing or decreasing the states of redox potential and solubility and thereby causing their mobilization or immobilization through complexation or precipitation (Lovley et al., 1998 ; Wildung et al., 2000). 
FROM SEDIMENTS OF LAKE MANZALAH, EGYPT

The purpose of the current research is to examine the role of dissolved humic and fulvic acids on the distribution of trace metals in surficial sediments of Lake Manzalah.

\section{Area of study}

\section{MATERIALS AND METHODS}

Lake Manzalah is one of four coastal lakes situated at the northern region of Nile Delta. It is a shailow brackish ecosystem, lies between long $31^{\circ} 45^{\prime}, 32^{\circ} 15^{\prime} \mathrm{E}$ and Lat. $31^{\circ} 00^{\prime}, 31^{\circ} 35^{\prime} \mathrm{N}$. It covers an area of about $699 \mathrm{Km}^{2}$ (Samir, 2000), with an average depth of $1 \mathrm{~m}$. It is connected with the Mediterranean Sea through a short channel (Boughaz El-Gamil). The Lake receives annually about $7500 \times 10^{6} \mathrm{~m}^{3}$ drainage waters (Abdel-Baky et al., 1991 ; El-Sherif \& Gharib, 2001). The wastewaters are discharged through six drains, located at the southeastern part of the lake; industrial and sewage wastes (Bahr El-Baqar drain); sewage wastes (El-Matariya drain) and agricultural drains (Ramses, Hadus, El-Gammaliya and El-Sirw drains).

\section{Samples collection and preparation}

Twelve sediment samples were collected from Lake Manzalah by plastic cylinder ( PVC ) $6 \mathrm{~cm}$ in diameter (Fig. 1). Sample sites were selected to represent all the different degrees of influence by sewage, industrial and agricultural wastewater. Plastic tube was forced gently into the upper layer of the sediments $(20 \mathrm{~cm})$. Wet sediments were taken to the laboratory in polyethylene bags. Sub sample was left dry in air in Petri- dishes at room temperature. After separating of foreign solids and moliusk shells, air dried sediment was homogenized with a pestle and mortar to normalize for variations in grain size distribution and sieved through $2 \mathrm{~mm}$ mesh size sieve.

\section{Extraction, fractionation and purification of humic substances}

Sediments humic and fulvic materials were doubly extracted from the sediments with $0.5 \mathrm{M}$ Sodium hydroxide $(\mathrm{NaOH})$ solution with a sediment/extraction ratio of $1: 4 \mathrm{~g} / \mathrm{ml}$ under nitrogen gas (Alvarez et al., 2004). Samples were extracted overnight in an end-over-end shaker in polyethylene centrifuge tubes and then again for 3-4h with fresh $\mathrm{NaOH}$ solution. The samples were then centrifuged to remove these materials from the supernatant containing dissolved humic and fulvic acids. Following centrifuging, the supernatant was filtered and acidified to $\mathrm{pH}$ 1.5 using $6 \mathrm{~N} \mathrm{HCl}$ at which only the fulvic material is soluble (Alvarez et 
$a l ., 2004)$.The precipitated humic acid was then allowed to settle. At this point, humic and fulvic acids were treated separately by vacuumsiphoning the fulvic-containing supernatant. The supernatant of fulvic acid was purified using amberlite XAD-8 resin (Gondar et al., 2004) and remove inorganic impurities, followed by several washes with deionized distilled water until the outlet solution did not contain chloride (negative silver chloride test).

The humic acids, which had been precipitated earlier, were centrifuged and washed several times with $0.1 \mathrm{M} \mathrm{HCl}$ followed by washing with deionized distilled water. Humic material was dissolved using $0.1 \mathrm{M} \mathrm{KOH}$ and then centrifuged to remove suspended solids. Reprecipitate the humic acid with $6 \mathrm{M} \mathrm{HCl}$ to $\mathrm{pH} 1.0$. suspend the humic acid precipitate in $0.1 \mathrm{M} \mathrm{HCl} / 0.3 \mathrm{M} \mathrm{HF}$ solution in a plastic container, shake overnight at room temperature, following centrifuging (this step was repeated to reduce the ash content below 1\%). The precipitate was dialyzing against DDW until the dialysis water gives a negative $\mathrm{Cl}$ test with the $\mathrm{AgNO}_{3}$. Finally, the humic and fulvic acids were freeze-dried for trace metals analysis. The extraction yields of dried humic and fulvic acids were determined gravimetrically and reported as $\mathrm{mg}$ ash-free per $100 \mathrm{gm}$ dry sediments and as a percentage of total organic matter.

\section{Trace metal measurements}

The powder of humic and fulvic acids was digested in cleaned and dried Teflon beaker at $140{ }^{\circ} \mathrm{C}$ for 10 hours, using mixture acids HNO3/HCl, 3:1 (El-Sayed et al., 1991). The total trace metals in the sediments were analyzed according to Oregioni and Aston (1984),0.1g of dried sediment was digested using mixture acids (HNO3/HClO4/HF, 3:2:1). After complete acid dissolution, the resulting solution was measured for trace metals( AAS, Perkin Elmer model 373)

\section{RESULTS AND DISCUSSION}

Table (1) shows the contents of organic matter in the sediments of Lake Manzalah. There is enrichment of the sediments with organic matter (1.96-8.41\%). The quantities of total humic substances extracted from the sediment samples were ranged from 1029 to $6290 \mathrm{mg} / \mathrm{kg}$ for humic acid and from 520 to $2310 \mathrm{mg} / \mathrm{kg}$ for fulvic acid. The high contents of humic substances of the sediments could be attributed to their high contents of organic matter. 
The levels of trace metal concentrations in the humic and fulvic acids at different stations are shown in Tables 2 and 5. The enrichment factor for trace metals in the humic and fulvic acids are recorded in Tables 3 and 6 . The enrichment factor defined as ratio of a metal concentration in humic or fulvic acid to its concentration in the associated sediments.

The results revealed high concentration of trace metals are associated with the humic acid compared to fulvic acid at the most stations. (Tables 2 and 5). This was in agreement with that reported by Nriagu and Coker (1980). Other studies which they also reported higher content of trace metals are associated with humic acids compared to fulvic acids (Okbah et al., 1997). The present data showed high accumulation of iron, copper and zinc in humic and fulvic acids from Lake Manzalah sediments (Tables 2 and 5).

Trace metal concentrations in the humic acid showed considerably high contents of iron (1046-3069 $\mu \mathrm{g} / \mathrm{g}$ ); copper (234-1498 $\mu \mathrm{g} / \mathrm{g}$ ) and zinc (110-394 $\mu \mathrm{g} / \mathrm{g}$ ). The other trace metals (Co, Cd, $\mathrm{Cr}, \mathrm{Ni}$ and $\mathrm{Mn}$ ) showed relatively low concentration, ranged from 11.3 to $156 \mu \mathrm{g} / \mathrm{g}$.

Nriagu \& Coker (1980) suggested that the metal contents of the humic acids are strongly influenced by the metal contents of the precursor organic matter. Also, they pointed that the introduction of metals into HA and fulvic acid is strongly dependent on the forms of the metals present as well as on the diagenetic processes.

The metal concentrations in fulvic acid extracted from Lake Manzalah sediments were in the following order $\mathrm{Fe}(465-2767 \mu \mathrm{g} / \mathrm{g}) ; \mathrm{Cu}$ (49.6-250.6 $\mu \mathrm{g} / \mathrm{g}) ; \mathrm{Zn}(49.3-186.6 \mu \mathrm{g} / \mathrm{g}) ; \mathrm{Cd}(39.6-80.8 \mu \mathrm{g} / \mathrm{g}) ; \mathrm{Ni}(20.4-$ $153.4 \mu \mathrm{g} / \mathrm{g}) ; \mathrm{Co}(12.5-78.0 \mu \mathrm{g} / \mathrm{g}) ; \mathrm{Mn}(11.8-55.9 \mu \mathrm{g} / \mathrm{g})$ and $\mathrm{Cr}(9.1-39.6$ $\mu \mathrm{g} / \mathrm{g})$.

The copper enrichment factor was higher than 1.0, ranged from 3 to 24 for humic acid and from 1.5 to 10 for fulvic acid. Tables 3 and 6 showed that the cadmium enrichment factor was greater than that of copper, it ranged from 6 to 196 in humic acid and from 7 to 236 in fulvic acid. In addition to $\mathrm{Cu}$ and $\mathrm{Cd}$, the most of samples revealed enrichment factors more than 1.0 in humic acid, including Co (1.03-4.6) and $\mathrm{Ni}(1.1-4.5)$, while in the fulvic acid were (1-3) for Co and (1-3.6) for Ni. On the other hand, the enrichment factors for the other metals $(\mathrm{Cr}, \mathrm{Zn}$, $\mathrm{Fe}$ and $\mathrm{Mn}$ ) were less than 1.0. This can be explained by the high 
Mohamed A. Okbah and Mohamed A. Hamed

concentration in the sediments than the levels observed in the humic substances.

The percentage of trace metals associated with humic and fulvic acids are recorded in Tables 4 and 7 . It is clear that $\mathrm{Cu}$ and $\mathrm{Cd}$ percentages associated with the humic acid were high comparing with that reported in the other metals. It is represented by $1-6 \%$ for $\mathrm{Cu}$ and 1 $23 \%$ for $\mathrm{Cd}$. The relative percentage was decreased for the same metals in association with fulvic acid; less than $0.5 \%$ for $\mathrm{Cu}$ for all station, except station IV (0.83\%), while the Cd percentage, bound to the fulvic acid showed high levels $(<1.0$ to $13 \%$ ). It was estimated that $<0.10 \%$ of the other metals ( $\mathrm{Co}, \mathrm{Cr}, \mathrm{Ni}, \mathrm{Zn}, \mathrm{Fe}$ and $\mathrm{Mn}$ ) are bound to the fulvic acid. The high levels of $\mathrm{Cu}$ and $\mathrm{Cd}$ accumulated by humic and fulvic acids can be explained by strong affinity of HA and FA for the two metals. The high accumulation of $\mathrm{Cu}$ and $\mathrm{Fe}$ by $\mathrm{HA}$ was also observed in Lake Ontario (Nriagu \& Coker, 1980)

On the other hand, the low percentage of the other metals may be due to the inability of these metals to compete with $\mathrm{Cu}$ and $\mathrm{Cd}$ for binding sites in the humic substances. The other interpretation explanation is the subsequent displacement of trace metals from the binding sites in the humic substances by $\mathrm{Cu}$ and $\mathrm{Cd}$. Callendar \& Bowser (1980) suggested that copper is mainly transported to the sediment surface in association with a biogenic carrier. Chester et al. (1988) reported that $50 \%$ of the total $\mathrm{Cu}$ in the surface water particulates is held in organic association and deposited at the sediment surface. Niriagu \& Coker (1980) found that the humic acid isolated from Lake Ontario sediments contained higher concentration of copper than the fulvic acid isolated from the same site (10-20\% of the copper is bound to the humic acids). According to the results obtained by El-Sayed et al. (1991), the relative concentration of $\mathrm{Cu}$ in the humic substances of Lake Edku was between $2.03 \%$ and $43.04 \%$. The organic-Cu fraction in the surficial sediments of Lake Burullus ranged from 3.44 and $10.4 \%$ (Okbah, 1991), the value increased to reach $26.8 \%$ for the organic-Cu fraction in the surficial sediment of Lake Nasser (Shata et al., 1993).

The distribution of $\mathrm{Ni}$ in the HA and FA did not have the same trend of both $\mathrm{Cu}$ and $\mathrm{Zn}$. The results showed that the levels of $\mathrm{Ni}$ content were high in FA at stations IV and V. The opposite was recorded in the other stations, which the high concentration of $\mathrm{Ni}$ was found in the HA. This may be related to the high content of $\mathrm{CaCO}_{3}$ at these sites (60-67\%). $\mathrm{Ni}$ and $\mathrm{Ca}$ ions strongly compete with each other for reactions with the 
humic acid. The results recorded by Zhou et al. (2005) indicated that high concentrations of $\mathrm{Ca}$ in the contaminated water could strongly inhibit the complexation of $\mathrm{Ni}$ ions, whereas an increase in $\mathrm{pH}$ and the humic concentration could attenuate such competitive interactions.

Generally, the ability of metal complexation with humic substances is critical in evaluating heavy metal reactivity, mobility and fate in the environment because $\mathrm{pH}$ is one of the most critical parameters in the chemistry of metal ions and humic substances (Zhou et al., 2005).

The most striking feature of zinc is the relative higher contributions of humic acid fraction compared to fulvic acid. $\mathrm{Zn}$ in the HA fraction ranged from 0.04 to $0.22 \%$ of the total. The higher value $(0.22 \%)$ was recorded at station IV, which is characterized by relative high content of organic matter $(7.93 \%)$; the considerable amount of carbonate $(37.80 \%)$ and the type sediment (clay loam), are favoring the absorption process. Nriagu \& Coker (1980) showed that the zinc associated with humic acids in Lake Ontario sediments contributed $0.18 \%$ and $0.39 \%$ of the total $\mathrm{Zn}$.

As shown in Table (8), the Co and Cu concentrations in the humic acid isolated from Lake Manzalah sediments were higher compared to the data of Lake Edku and Lake Mariut. On the other hand, the levels of $\mathrm{Cu}$ associated with fulvic acid were lower than that extracted from the sediments of Lake Mariut, Lake Edku and Lake Ontrario.

The results of the present work showed that the average concentration of $\mathrm{Ca}$ in the humic and fulvic acids extracted from Lake Manzalah sediments (Table 8) is higher three folds than that recorded in Lake Mariut (Okbah, 1997). The high levels of $\mathrm{Co}, \mathrm{Cu}$ and $\mathrm{Cd}$ may be related to the point sources of polluted waters from sewage and industrial wastewaters (Fig. 1).

\section{REFERENCES}

Abdel-Baky, T. E.; Hassan, S. H. and Shallof, K. A. H. (1991). Growth of cichlid species in Lake Manzalah, Egypt. Bull. Fac. Sci. Mans. Univ. 18 (2), 422-443.

Callender, E. and Bowser, C. J. (1980). Manganese and copper geochemistry of interstitial fluids from manganese nodule-rich sediments of the north-eastern equatorial Pacific Ocean. American Journal of Science 280: 1063-1096. 
Chen, J.; Baohua, G.; LeBoeuf, E. J.; Pan, H.; and Dai, S. (2002a). Spectroscopic characterization of the structural and functional properties of natural organic matter fractions (NOM). Chemosphere, 48: 59-68.

Chen, Jie; Baohua, G. U.; Royer, R. A.; and Burgos, W. D. (2003). The roles of natural organic matter in chemical and microbial reduction of ferric iron. The science of the total Environment. 307: 167-178.

Chin, Y. P.; Aiken, G.; and O'Loughlin, E. (1994). Molecular weight polydispersity and spectroscopic properties of aquatic humic substances: Environ. Sci. Tech.11:1853-1858.

El-Saraaf, W. M., (1995). Trace metals concentration of aquatic Macrophytes in lake Manzalah, Egypt Bull.Nat.Inst. of Oceanogr. \& Fish, A.R.E. 21 (1): 171-181.

El-Sayed, M. A.; Beltagy, A. I.; Aboul Naga, W. and Halim, Y. (1991). Role of humic substances in the accumulation of trace metals in bottom sediments. Proceeding symposium Marine Chemistry in the Arab Region, Suez, Egypt. Special Issue April: pp 239-254.

El-Shebly, A. A. (2002). Seasonal variations of some biochemical parameters in muscles Oreochromis Niloticus reared in Lake Manzalah fish farms. Bull. Nat. Inst. of oceanogr. \& Fish. A.R.E. 28:201:215.

El-Sherif, Z. M. and Gharib, S. M. (2001). Spatial and temporal patterns of phytoplankton communities in Manzalah Lagoon. Bull. Nat. Inst. of Oceanogr. \& Fish., A.R.E., 27: 217-239.

Fiol, S.; López, R.; Ramos, A.; Antelo, J. M. and Arce, F. (1999). Study of the acid-base properties of three fulvic acids extracted from different horizons of a soil. Anal. Chem. Acta 385: 443-449.

Gondar, D.; Lopez, R.; Fiol, S.; Antelo, J.M. and Arce, F. (2005). Characterization and acid-base properties of fulvic and humic acids isolated from two horizons of an ambrotrophic peat bog. Geoderma 126: 367-374. 
Hayes, M. H. B. and Swift, R. S. (1990). Genesis isolation, composition, and structures of soil humic substances. In M.F. de Boodt, M.H.B. Hayes and A. Herbillon (eds.) soil colloids and their associations in aggregates. New York: Plenum press, pp. 245-305.

Ibrahim, M. A.; Mousa, A. A. and El-Bokhty, El. A. (1997). Environmental factors affecting abundance and distribution of macro benthic organisms in Lake Manzalah, Egypt. Bull. Nat. Inst. of oceanogr. \& Fish. A.R.E., 23: 315-331.

LeBoeuf, E. J. and Weber, W. J. (2000). Macromolecular characteristics of natural organic matter. 2. Sorption and desorption behavior. Environmental Science and Technology. 34: 3632-3640.

Liu, A. and Gonzalez, R. D. (1999). Adsorption/Desorption in system consisting of humic acid, heavy metals and clay minerals. $J$. Colloid and Interface Sci. 218: 225-232.

Lovley, D. R.; Frago; J. L.; Blunt-Harris; E.L.; Hayes, L.A.; Phillips, E. J. P. and Coates, J. D. (1996). Humic substances as a mediator for microbial catalyzed metal reduction. Acta Hydrochim Hydrobiol. 26: $152-157$.

Nissenbaum, A. and Swaine, D. J. (1976). Organic matter-metal interactions in recent sediments: the role of humic substances. Geochemica et Cosmochimica Acta. 40: 816

Nriagu, J. O. and Coker, R. D. (1980). Trace metals in humic and fulvic acids from Lake Ontario sediments. Environmental Science \& Technology. 14 (4): 443-446.

Okbah, M. A. (1991). The distribution of Fe, $\mathrm{Mn}, \mathrm{Zn}$ and $\mathrm{Cu}$ forms in the surficial sediments of Burullus Lake. M.SC. Thesis, Faculty of Agriculture. Alexandria University, Egypt.

Okbah, M. A.; Kaloosh, A. A. M.; El-Deek, M. S. and El-Attar, H. A. (1997). Trace Metal $(\mathrm{Cu}, \mathrm{Zn}, \mathrm{Pb}, \mathrm{Cr}$ and $\mathrm{Cd})$ concentrations of three sub-fractions of organic matter from Lake Mariut sediments, Egypt. Pakistan Journal of Marine Sciences, 6 (1 and 2): 13-25. 
Plaza, C.; D'Orazio, V. and Senesi, N. (2005). Copper (II) Complexation of humic acids from the first generation of EUROSOILS by total luminescence spectroscopy. Geoderma 125: 177-186.

Schnitzer, M., (1989). Binding of humic substances by soil mineral colloids. In P.M. Huang and M. Schnitzer (Eds.). Interactions of soil minerals with natural organics and microbes. SSSA special publication no. 17, Madison, Wisconsin: Soil Science Society of America, Inc. pp. 77-101.

Shata, M. A.; El-Deek, M. S. and Okbah, M.A. (1993). Fractionation of $\mathrm{Mn}, \mathrm{Fe}, \mathrm{Zn}$ and $\mathrm{Cu}$ in sediments of Khor Kalabsha, Lake Nasser, Egypt. Chemistry and Ecology. 8: 89-103

Stevenson, F. J. (1994). Humus Chemistry: Genesis, Composition, Reactions, $2^{\text {nd }}$ ed. Wiley, New York.

Swift, R.S.(1989). Molecular weight, size, shape and charge characteristics of humic substances; some basic considerations. In:Hayes, M.H.B. MacCarthy, P., Malcolm, R.L.,Swift, R.S.(Eds.) Humic substances:II. John Wiley and sons, New York pp.449465.

Swift, R. S. (1996). Organic matter characterization. In: sparks, D.L., et al., (Ed.). Methods of soil Analysis: part 3, Chemical Methods, SSSA Book Series 5. Soil Science Society of America, Madison, WI, pp. 1018-1020.

Wildung, R. E.; Gorby, Y. A.; Krupka, K. M.; Hess, N. J.; Li, S. W.; plymale, A. E.; Mckinley, J. P. and Fredrickson, J. K. (2000). Effect of electron donor and solution chemistry on products of dissimulator reduction of technetium by shewanella put refacients. Appl. Environ. Microbiol. 66: 2451-2460.

World Health organization, WHO, (1992). Cadmium, Environmental Health Criteria 135. ISBN 9241571357. 
TRACE METALS BINDING TO HUMIC AND FULVIC ACIDS

Zhou, J. L.; Rowland, S.; Fauzi, R.; Mantoura, C. and Braven, J. (1994). The formation of humic coatings on mineral particles under simulated estuarine conditions. A mechanistic study. Water Research 28: 571-579.

Zhou, P.; Yan, H. and GU, B. (2005). Competitive complexation of metal ions with humic substances. J. Chemosphere. 28: 1327-1337. 
Table 1: Organic matter, humic acid, fulvic acid and total trace metal concentrations of Lake Manzalah during summer 2004.

\begin{tabular}{|c|c|c|c|c|c|c|c|c|c|c|c|}
\hline Organic & Humic & \%Humic & Fulvic & $\%$ Fulvic & \multicolumn{7}{|c|}{ Total Trace metals ( $\mu \mathrm{g} / \mathrm{g}$ ) } \\
\hline & acid & acid & acid & acid & Co & $\mathrm{Cd}$ & $\mathrm{Cr}$ & $\mathrm{Cu}$ & $\mathrm{Ni}$ & $\mathrm{Zn}$ & Fe \\
\hline $8.4 !$ & 1550 & 6.40 & 730 & 3.00 & 37 & 1.27 & 47 & 98 & 70 & 414 & 11582 \\
\hline 5.52 & 1970 & 8.20 & 1020 & 4.20 & 55 & 1.81 & 54 & 101 & 79 & 424 & 11828 \\
\hline 4.41 & 1480 & 3.60 & 920 & 1.70 & 43 & 1.88 & 65 & 91 & 73 & 379 & 11360 \\
\hline 7.93 & 6290 & 7.90 & 2109 & 2.70 & 19 & 1.68 & 28 & 21 & 62 & 275 & 9184 \\
\hline 6.31 & 1960 & 3.10 & 1040 & 1.60 & 28 & 1.98 & 74 & 90 & 29 & 367 & 11431 \\
\hline 6.89 & 1029 & 1.50 & 520 & 0.80 & 34 & 1.95 & 93 & 56 & 42 & 377 & 10952 \\
\hline 1.96 & 1160 & 1.30 & 610 & 0.70 & 23 & 1.64 & 83 & 32 & 52 & 413 & 9188 \\
\hline 2.28 & 2050 & 2.50 & 1180 & 1.40 & 32 & 1.65 & 71 & 28 & 26 & 402 & 9802 \\
\hline 2.07 & 2090 & 10.10 & 1098 & 5.30 & 31 & 2.51 & 88 & 36 & 28 & 402 & 10834 \\
\hline 5.86 & 4180 & 7.13 & 2310 & 3.94 & 46 & 1.54 & 85 & 55 & 49 & 470 & 11688 \\
\hline 2.07 & 1770 & 8.60 & 1048 & 5.10 & 34 & 1.46 & 93 & 44 & 60 & 450 & 11141 \\
\hline 1.83 & 1410 & 2.92 & 594 & 1.23 & 27 & 1.57 & 84 & 37 & 41 & 491 & 10787 \\
\hline 1.96 & & 1.30 & & 0.70 & 19 & 1.27 & 28 & 21 & 26 & 275 & 9184 \\
\hline 8.41 & & 10.10 & & 5.30 & 55 & 2.51 & 93 & 101 & 79 & 491 & 11828 \\
\hline 4.92 & & 5.33 & & 2.69 & 34 & 1.8 & 70 & 58 & 51 & 402 & 10771 \\
\hline
\end{tabular}


TRACE METALS BINDING TO HUMIC AND FULVIC ACIDS FROM SEDIMENTS OF LAKE MANZALAH, EGYPT

Table 2: Trace metal concentrations ( $\mathrm{mg} / \mathrm{kg}$ ) in humic acid extraction from Lake Manzalah sediments during summer, 2004.

\begin{tabular}{|c|l|l|l|l|l|l|l|l|}
\hline Station & $\mathrm{Co}$ & $\mathrm{Cd}$ & $\mathrm{Cr}$ & $\mathrm{Cu}$ & $\mathrm{Ni}$ & $\mathrm{Zn}$ & $\mathrm{Fe}$ & $\mathrm{Mn}$ \\
\hline $\mathrm{I}$ & 15.50 & 35.40 & 31.80 & 1209.50 & 83.80 & 142.50 & 2050.00 & 19.80 \\
\hline $\mathrm{II}$ & 97.60 & 33.50 & 24.10 & 258.60 & 91.40 & 195.10 & 2783.00 & 59.60 \\
\hline $\mathrm{III}$ & 95.80 & 31.70 & 51.00 & 502.00 & 156.00 & 394.00 & 1736.00 & 36.60 \\
\hline $\mathrm{IV}$ & 60.90 & 43.60 & 38.80 & 234.00 & 17.80 & 110.40 & 1908.00 & 61.90 \\
\hline $\mathrm{V}$ & 130.50 & 54.30 & 35.10 & 1498.00 & 16.40 & 144.90 & 1046.00 & 30.40 \\
\hline $\mathrm{VI}$ & 17.90 & 65.60 & 77.50 & 357.50 & 46.50 & 159.30 & 1689.00 & 96.50 \\
\hline $\mathrm{VII}$ & 11.30 & 59.00 & 25.10 & 427.80 & 104.30 & 113.40 & 908.00 & 17.80 \\
\hline $\mathrm{VIII}$ & 88.40 & 53.40 & 39.60 & 293.80 & 98.60 & 250.00 & 3069.00 & 47.60 \\
\hline $\mathrm{IX}$ & 68.60 & 46.50 & 34.10 & 396.90 & 123.90 & 138.40 & 1135.00 & 19.00 \\
\hline $\mathrm{X}$ & 172.30 & 38.10 & 29.50 & 425.00 & 58.20 & 125.00 & 1711.00 & 41.50 \\
\hline $\mathrm{XI}$ & 181.60 & 42.40 & 34.30 & 531.50 & 63.70 & 113.10 & 1578.00 & 47.30 \\
\hline $\mathrm{XII}$ & 64.10 & 51.70 & 31.60 & 346.10 & 80.40 & 127.30 & 1820.00 & 35.40 \\
\hline
\end{tabular}

Table 3: Enrichment factors for trace metals in the humic acids, Lake Manzalah sediments during Summer 2004.

\begin{tabular}{|l|l|l|l|l|l|l|l|l|}
\hline Station & $\mathrm{Co}$ & $\mathrm{Cd}$ & $\mathrm{Cr}$ & $\mathrm{Cu}$ & $\mathrm{Ni}$ & $\mathrm{Zn}$ & $\mathrm{Fe}$ & $\mathrm{Mn}$ \\
\hline $\mathrm{I}$ & 0.41 & 6.86 & 0.39 & 16.74 & 1.03 & 0.38 & 0.18 & 0.02 \\
\hline II & 1.79 & 30.91 & 0.22 & 3.46 & 1.02 & 0.52 & 0.24 & 0.06 \\
\hline III & 2.29 & 8.21 & 0.41 & 7.30 & 2.12 & 0.21 & 0.15 & 0.04 \\
\hline IV & 3.21 & 7.68 & 0.88 & 16.00 & 1.09 & 0.57 & 0.21 & 0.20 \\
\hline $\mathrm{V}$ & 4.64 & 9.64 & 0.59 & 24.20 & 1.05 & 0.44 & 0.09 & 0.05 \\
\hline VI & 1.03 & 11.79 & 0.84 & 9.45 & 1.09 & 0.56 & 0.15 & 0.12 \\
\hline VII & 1.08 & 196.70 & 0.48 & 21.30 & 2.00 & 0.32 & 0.10 & 0.02 \\
\hline VIII & 2.75 & 17.67 & 0.66 & 17.80 & 3.81 & 0.80 & 0.31 & 0.06 \\
\hline IX & 2.19 & 13.14 & 0.49 & 14.60 & 4.48 & 0.43 & 0.10 & 0.02 \\
\hline $\mathrm{X}$ & 1.57 & 6.79 & 0.29 & 10.20 & 1.18 & 0.31 & 0.15 & 0.06 \\
\hline $\mathrm{XI}$ & 2.38 & 7.50 & 0.52 & 15.70 & 1.07 & 0.30 & 0.14 & 0.08 \\
\hline $\mathrm{XII}$ & 2.46 & 9.45 & 0.53 & 14.90 & 1.95 & 0.34 & 0.17 & 0.07 \\
\hline \hline
\end{tabular}


Table 4: Percentage of metal assocjated with humic acids, Lake Manzalah sediments during summer 2004

\begin{tabular}{|c|c|c|c|c|c|c|c|c|}
\hline Station & $C_{0}$ & $\mathrm{Cd}$ & $\mathrm{Cr}$ & $\mathrm{Tu}_{\mathrm{Cu}}$ & $\sqrt{\mathrm{i}}$ & $\mathrm{Zn}$ & $\mathrm{Fe}$ & $\mid \mathrm{Mn}$ \\
\hline I & 0.01 & 0.98 & 0.06 & 2.60 & 0.08 & 0.06 & 0.03 & 0.01 \\
\hline II & 0.02 & 6.36 & 0.04 & 0.68 & 10.20 & 0.10 & 90.05 & 0.01 \\
\hline III & 0.03 & $\lceil 1.28$ & 0.06 & 11.08 & $\sqrt{0.32}$ & 10.18 & 10.02 & 0.01 \\
\hline IV & 0.01 & 2.86 & 1.88 & 6.15 & 0.11 & 0.22 & T0.08 & 0.08 \\
\hline $\bar{V}$ & 0.01 & $\longdiv { 1 . 9 6 }$ & 0.44 & 4.70 & $\overline{0.10}$ & 0.09 & 10.02 & 10.01 \\
\hline $\mathrm{VI}$ & 0.01 & $\longdiv { 1 . 2 5 }$ & 0.11 & $\overline{0.95}$ & 0.12 & 10.06 & 0.02 & $\sqrt{0.01}$ \\
\hline VII & $10.0 \mathrm{I}$ & 23.30 & $\sqrt{0.06}$ & 2.50 & 0.23 & 0.04 & 0.01 & 0.01 \\
\hline VIII & 0.01 & 3.67 & 0.14 & 3.60 & 0.77 & $\sqrt{0.16}$ & 10.06 & 0.0 \\
\hline IX & 0.01 & 2.86 & 0.10 & 3.05 & 0.93 & 0.09 & 0.03 & 0.01 \\
\hline $\bar{X}$ & 70.01 & 2.86 & 0.12 & 4.30 & 0.49 & 0.13 & 0.06 & 0.02 \\
\hline$X I$ & 0.01 & 1.25 & 0.09 & 2.80 & 0.18 & 0.05 & 0.03 & 0.01 \\
\hline $\mathrm{XII}$ & 0.01 & 1.27 & 0.07 & {$\left[2.10^{\circ}\right.$} & 0.27 & $\lcm{0.05}$ & 0.02 & 0.02 \\
\hline
\end{tabular}

Table 5: Trace melal concentrations $(\mathrm{mg} / \mathrm{kg}$ ) in fulvic acid extraction, Lake Manzalah sediments during summer, 2004.

\begin{tabular}{|l|l|l|l|l|l|l|l|l|}
\hline Station & $\mathrm{Co}$ & $\mathrm{Cd}$ & $\mathrm{Cr}$ & $\mathrm{Cu}$ & $\mathrm{Ni}$ & $\mathrm{Zn}$ & $\mathrm{Fe}$ & $\mathrm{Mn}$ \\
\hline $\mathrm{I}$ & 35.10 & 96.10 & 16.40 & 240.00 & 20.40 & 186.60 & 2678.00 & 41.30 \\
\hline $\mathrm{II}$ & 46.50 & 80.80 & 99.10 & 163.30 & 76.30 & 172.30 & 2767.00 & 55.90 \\
\hline $\mathrm{III}$ & 41.30 & 77.20 & 339.60 & 99.80 & 54.60 & 101.10 & 2330.00 & 13.80 \\
\hline $\mathrm{IV}$ & 14.80 & 39.60 & 32.30 & 102.70 & 60.20 & 125.30 & 2300.00 & 15.60 \\
\hline $\mathrm{V}$ & 12.50 & 43.40 & 31.90 & 119.90 & 175.80 & 126.70 & 1165.00 & 23.80 \\
\hline $\mathrm{VI}$ & 17.40 & 78.60 & 27.40 & 125.20 & 153.40 & 137.20 & 1240.00 & 20.20 \\
\hline VII & 20.10 & 71.20 & 33.20 & 49.60 & 48.80 & 49.30 & 574.00 & 45.40 \\
\hline $\mathrm{VII}$ & 64.60 & 60.70 & 30.80 & 50.80 & 53.60 & 52.60 & 682.00 & 41.70 \\
\hline $\mathrm{IX}$ & 58.20 & 54.60 & 13.20 & 124.10 & 89.10 & 57.80 & 465.00 & 12.50 \\
\hline $\mathrm{X}$ & 57.10 & 67.50 & 15.70 & 130.20 & 47.80 & 60.40 & 524.00 & 16.40 \\
\hline $\mathrm{XI}$ & 59.00 & 71.40 & 13.80 & 149.80 & 41.30 & 112.00 & 827.00 & 11.80 \\
\hline $\mathrm{XII}$ & 78.00 & 65.80 & 12.60 & 250.60 & 43.90 & 137.80 & 917.00 & 36.40 \\
\hline
\end{tabular}


TRACE METALS BINDING TO HUMIC AND FUEVIC ACIDS FROM SEDIMENTS OF LAKE MANZALAH, EGYPT

Table 6: Enrichment factors for trace metals in the fulvic acids, Lake Manzalah Sediments during summer 2004.

\begin{tabular}{|c|c|c|c|c|c|c|c|c|}
\hline Station & $\mathrm{Co}$ & $\Gamma_{\mathrm{Cd}}$ & $\overline{C r}$ & $\mathrm{Cu}$ & Ni & $\mathrm{Zn}$ & $\mathrm{Fe}$ & Min \\
\hline I & 1.00 & 13.53 & 0.20 & 3.32 & $\lceil 0.13$ & 0.50 & 0.23 & 0.05 \\
\hline II & 1.00 & 73.64 & 0.80 & 2.18 & 1.00 & 0.46 & 0.23 & 0.06 \\
\hline III & 11.00 & 19.74 & 0.32 & 1.46 & 11.00 & 0.31 & 0.21 & 0.02 \\
\hline IV & 1.00 & $7 . \overline{14}$ & 0.40 & 17.03 & 1.00 & 0.65 & 0.25 & 0.05 \\
\hline $\mathrm{v}$ & 0.43 & 7.68 & 0.54 & 1.94 & 6.07 & 0.39 & 0.15 & 0.04 \\
\hline VI & 0.50 & 13.93 & 0.36 & 3.29 & 3. 3.64 & 0.48 & 0.11 & 0.03 \\
\hline VII & 1.00 & 236.70 & 0.63 & 2.48 & 1.00 & 10.14 & 0.06 & 0.06 \\
\hline VIII & 2.00 & 20.30 & 0.53 & 3.07 & 2.08 & 0.17 & 0.07 & 0.05 \\
\hline IX & 1.87 & 15.43 & 0.19 & 4.56 & 3.18 & 0.18 & 0.04 & 0.01 \\
\hline$x$ & 1.24 & [1 1.96 & 0.15 & 3.11 & 1.00 & 0.15 & 0.04 & 0.02 \\
\hline $\mathrm{XI}$ & 1.74 & 10.54 & 0.21 & 4.42 & 1.00 & 0.29 & 10.07 & $\mid 0.02$ \\
\hline $\mathrm{XII}$ & 3.00 & 114.20 & 0.20 & 10.81 & 1.07 & 10.37 & 0.09 & 10.08 \\
\hline
\end{tabular}

Table 7: Percentage of metal associated with fulvic acids, Lake Manzalah sediments during summer 2004.

\begin{tabular}{|c|c|c|c|c|c|c|c|c|}
\hline Station & 'Co & $\mathrm{Cd}$ & $\mathrm{iCr}$ & $\mathrm{Cu}$ & $\mathrm{Ni}$ & $\mathrm{Zn}$ & $\mathrm{Fe}$ & $\mathrm{Mn}$ \\
\hline 1 & $<0.01$ & $\prod 1.18$ & 10.01 & 0.2 & 0.01 & 0.04 & 0.02 & $\mid<0.01$ \\
\hline II & {$[<0.01$} & 7.27 & 0.01 & 0.23 & 0.09 & 0.05 & 10.02 & 100.01 \\
\hline III & $<0.1$ & 2.05 & 0.03 & 0.16 & 0.08 & 0.03 & 0.02 & $7<0.01$ \\
\hline IV & $<0.01$ & 0.89 & 0.05 & 0.83 & 0.11 & 0.08 & 0.03 & $<0.01$ \\
\hline V & $<0.01$ & 0.54 & 0.03 & 0.11 & 0.34 & 0.02 & 10.01 & $<0.01$ \\
\hline$\overline{\mathrm{VI}}$ & $<0.01$ & 1.07 & 0.03 & 0.26 & 0.29 & 0.04 & 0.01 & $k 0.01$ \\
\hline$\overline{\text { VII }}$ & $<0.01$ & 13.3 & 0.04 & 10.15 & 0.06 & $: 0.01$ & 0.01 & $<0.01$ \\
\hline VIII & $<0.01$ & 2.33 & 0.07 & 0.36 & 0.27 & 0.02 & 0.01 & $k<01$ \\
\hline IX & $<0.01$ & 0.86 & $10.0 \mathrm{I}$ & 0.26 & 0.19 & 0.01 & 0.01 & $<0.01$ \\
\hline$x$ & $<0.01$ & {$[0.7]$} & 0.01 & 0.17 & 0.06 & 0.01 & 0.01 & $<0.01$ \\
\hline $\mathrm{XI}$ & $<0.01$ & 0.71 & 10.02 & 0.27 & 0.05 & 0.02 & 0.01 & $\mid<0.01$ \\
\hline XII & $<0.01$ & 0.36 & 10.02 & 0.35 & 0.02 & 0.01 & 0.01 & $<0.01$ \\
\hline
\end{tabular}


Table 8: Range and average concentration of trace metals bound to humic and fulvic acids $(\mu \mathrm{g} / \mathrm{g})$ compared to the reported values in other Lakes.

\begin{tabular}{|c|c|c|c|c|c|c|c|c|}
\hline Metals & $\begin{array}{l}\text { Lake } \\
\text { Manzalah } \\
\text { Prescnt } \\
\text { study }\end{array}$ & & $\begin{array}{c}\text { Lake } \\
\text { Maruit } \\
\text { Okbah et } \\
\text { al., } 1997\end{array}$ & & $\begin{array}{l}\text { Lake Edku } \\
\text { El-Sayed } \\
\text { el al.,1991 }\end{array}$ & & $\begin{array}{l}\text { Lake Ontario } \\
\text { Nriago\&Coker, } 1980\end{array}$ & - \\
\hline & Rang & Average & Rang & Average & Rang & Average & Rang & Avere \\
\hline Coablt HA & {$\left[\begin{array}{l}11.3- \\
130.5\end{array}\right.$} & 67.04 & & & $32.0-69.0$ & 47 & $8.0-14.0$ & 11.0 \\
\hline FA & $12.5-78.0$ & 42.05 & & & $24.0-40.0$ & 32 & 2.0 & \\
\hline Cadmium HA & $31.7-65.6$ & 46.27 & $2.0-29.0$ & 14 & & & $0.9-1.30$ & 1.1 \\
\hline $\mathrm{FA}$ & $39.6-96.1$ & 67.24 & $3.0-26.0$ & {$[1]$} & & & 0.1 & \\
\hline Chromium HA & $24.1-77.5$ & 37.71 & $103-391$ & 192 & & & $27.0-31.0$ & 29.0 \\
\hline $\mathrm{FA}$ & $9.1-39.6$ & 23.00 & $36-477$ & 122 & i & & $1.0-20.0$ & \\
\hline Copper HA & $234-1498$ & 540.06 & $172-1090$ & 399 & $\begin{array}{l}90.0 \\
479.0\end{array}$ & 319 & $1306-1415$ & 1360 \\
\hline FA & $\begin{array}{l}49.6- \\
250.6\end{array}$ & 133.83 & $116-1238$ & 476 & $91.0-198.0$ & 143 & $810-2461$ & 2040. \\
\hline Nickel HA & $\begin{array}{l}16.4- \\
156.0\end{array}$ & 78.42 & & & $\begin{array}{l}141.0- \\
323.0\end{array}$ & 208 & $128-240$ & 184.0 \\
\hline$F \Lambda$ & $\begin{array}{l}20.4- \\
175.8\end{array}$ & 72.10 & & & $87.0-262.0$ & 189 & $9.0-35.0$ & 22.0 \\
\hline Zinc HA & $\begin{array}{l}110.4- \\
394.0\end{array}$ & 167.78 & $154-2193$ & 807 & $97.0-234.0$ & 188 & $39.0 \cdot 146.0$ & 73.0 \\
\hline $\mathrm{FA}$ & $\begin{array}{l}49.3- \\
186.6\end{array}$ & 109.93 & $126-1328$ & 453 & $\begin{array}{l}263.0 \\
344.0\end{array}$ & 293 & $15.0-23.0$ & 19.8 \\
\hline Iron IHA & $908-3069$ & 1786.08 & & & $2313-2834$ & 2522 & $9850-12140$ & $1104:$ \\
\hline $\mathrm{FA}$ & $465-2767$ & 1372.40 & & & $1137-2341$ & 1756 & $788-1875$ & 1336. \\
\hline $\begin{array}{l}\text { Manganese } \\
\text { HA }\end{array}$ & $17.8-96.5$ & 42.78 & & & $73.0-240.0$ & 153 & $95-112.0$ & 103.0 \\
\hline FA & 11.8-55.9 & 27.90 & & & $43.0-250.0$ & 141 & $9.0-21.0$ & 15.0 \\
\hline
\end{tabular}

